\title{
Tannery Sludge Added in Commercial Substrate for Capsicum baccatum Pepper Seedlings Production
}

\author{
Sávio da Silva Berilli ${ }^{1}$, Rafael Nunes de Almeida ${ }^{2}$, Ramon Amaro de Sales ${ }^{3}$, Paola Alfonsa Vieira Lo Monaco ${ }^{4}$, \\ Ana Paula Cândido Gabriel Berilli ${ }^{1}$, Waylson Zancanella Quartezani ${ }^{5}$, Silvio de Jesus Freitas ${ }^{2}$, \\ Rodrigo Amaro de Salles ${ }^{6}$, Evandro Chaves de Oliveira ${ }^{1}$, Robson Ferreira de Almeida ${ }^{1}$ \\ $\&$ Raphael Magalhães Gomes Moreira ${ }^{1}$ \\ ${ }^{1}$ Instituto Federal de Educação, Ciência e Tecnologia do Espírito Santo, Campus Itapina, Colatina, Espírito \\ Santo, Brazil \\ ${ }^{2}$ Centro de Ciências e Tecnologias Agropecuárias, Universidade Estadual do Norte Fluminense Darcy Ribeiro, \\ Campos dos Goytacazes, Rio de Janeiro, Brazil \\ ${ }^{3}$ Departamento de Fitotecnia, Universidade Federal de Viçosa, Viçosa, Minas Gerais, Brazil \\ ${ }^{4}$ Instituto Federal de Educação, Ciência e Tecnologia do Espírito Santo, Campus Santa Teresa, Santa Teresa, \\ Espírito Santo, Brazil \\ ${ }^{5}$ Instituto Federal de Educação, Ciência e Tecnologia do Espírito Santo, Campus Montanha, Montanha, Espírito \\ Santo, Brazil \\ ${ }^{6}$ Centro de Ciências Agrárias e Engenharias, Universidade Federal do Espírito Santos, Alegre, Espírito Santo, \\ Brazil \\ Correspondence: Ramon Amaro de Sales, Departamento de Fitotecnia, Universidade Federal de Viçosa, CEP \\ 36570-900, Viçosa Minas Gerais, Brazil. E-mail: ramonamarodesales@hotmail.com
}

Received: May 14, $2019 \quad$ Accepted: July 14, $2019 \quad$ Online Published: September 30, 2019

doi:10.5539/jas.v11n16p172 URL: https://doi.org/10.5539/jas.v11n16p172

\begin{abstract}
Among the most used inputs in the seedling production stage, substrate has a higher cost when compared to fertilizers, trays and fungicides. The use of residues in addition to commercial substrates, reduces production costs and promotes greater sustainability in the agricultural and industrial production process. The objective of this study was to evaluate the tannery sludge added to commercial substrate in Capsicum baccatum pepper seedlings production, as well as to identify better proportions of the substrate composition integrated with tannery sludge for this seedling. Pepper seedlings were evaluated growing in substrates with eight different compositions of tannery sludge $(0 \%, 10 \%, 20 \%, 30 \%, 40 \%, 50 \%, 60 \%$ and $80 \%)$ in commercial substrates. A randomized block design with four replications was used. Plant height, stem diameter, crown diameter, dry matter of shoot and roots were evaluated, and Dickson quality index was obtained. The linear models were predominantly the most significant to explain the developmental response of the seedlings when the tannery sludge was added in the substrate. It was found that alternative substrate can be used in a proportion of $80 \%$ of tannery sludge and $20 \%$ of commercial substrate and contribute in Capsicum baccatum pepper seedlings production with greater vigor, besides decreasing the cost of these substrates.
\end{abstract}

Keywords: residues, olericulture, "dedo-de-moça", sustainable agriculture

\section{Introduction}

Pepper belongs to the genus Capsicum and is considered a vegetable widely appreciated as the seasoning and it has as a characteristic some species, fruits with high pungency, resulting in capsaicin production (Kehie et al., 2016). Like other vegetables, the cultivation of peppers is one of the activities with the potential to generate income between small and medium farmers, and can be marketed in natura, in the jelly form, as conserves and sauces, and in the form of paprika (Signorini et al., 2013).

Also, just like any other olericulture crop, the most important production stage is the seedling stage that ensures quality and successful production in the field (Oliveira et al., 2015). Therefore, the use of quality inputs, such as 
seeds, substrate, greenhouse structure, adequate irrigation, among others is of utmost importance to obtain seedlings with high vigor, to be grown in the field.

While investment in quality inputs reduce the risk of production losses, may be you could say excessive expenditure on the inputs reduces profitability. The most used input at the seedling stage is the commercial substrate due to its high nutrient content and sufficient organic matter levels that promotes its usage by olericulture producers (Sediyama et al., 2014). Therefore, the acquisition of these substrates is one of the factors that most increase the production cost.

Since there is a high cost involved in the use of the commercial substrates, there is need to explore other alternatives like agricultural residues that can be processed to substitute the commercial substrates or used as a complement. (Almeida al., 2017; Berrili et al., 2015; Berilli et al., 2018a; Mota et al., 2018; Chagas et al., 2019). This alternative reduces the seedling production costs, and also generates greater sustainability of agricultural and industrial activities that generate waste, which are often discarded in landfills or improper areas, causing degradation to the environment (Alves \& Barbosa, 2013).

Among the industrial activities that generate income in Brazil, the tanning processing is one of the worrisome activities, due to generating waste. Although this activity generates significant profits, contributing to the economic and social development of the country, it has been a concern mainly for the significant production of residues/effluents that are produced during the bovine leather tanning process (Sales et al., 2018a). For this material to be discarded, it is often necessary for the company to rent spaces in landfills, making the production process even more costly.

Hence, searching alternative ways to use residues from animal leather processing, as well as the possibility of its use in substrates for seedlings production can reduce the production costs in vegetable seedlings and leather processing (Silva Júnior et al., 2014). Therefore, it is expected that tannery sludge added in substrates for seedling production will favor the development of the seedlings and thus reduce the production cost.

The objective of this study was to evaluate the using tannery sludge in commercial substrate in Capsicum baccatum pepper seedlings production and to identify the best proportions of substrate composition for this production.

\section{Material and Methods}

The study was carried out at the seedling green house in Federal Institute of Education, Science and Technology of Espírito Santo-IFES, Campus Itapina (IFES-Campus Itapina), located at Rod. BR 259, Zona Rural de Colatina, Espírito Santo, Brazil. The experiment was conducted from March to May 2014, being used a sombrite with $50 \%$ of block of luminosity, endowed with the system of irrigation by automatic micro sprinkler keeping the seedlings always near the field capacity. We evaluated the development of UENF 1417 pepper seedlings from seeds. That genotype belongs to the species Capsicum baccatum var. pendulum, being popularly known as "dedo-de-moça".

A randomized block design with four replications and eight treatments were used, and the experimental unit had 10 seedlings. The seedlings were grown in polypropylene trays containing 128 cells. For each plot, three cell rows were prepared, and the seedlings of the central row were evaluated. Between the plots was left a cell row to avoid contamination of the substrates during the cultivation of the seedlings. The treatments differered as to the proportions of tannery sludge added to commercial Bioplant ${ }^{\mathbb{B}}$ substrate (Table 1).

The analyses of the agrometeorological favorability of mildew and B. cinerea occurrence were simulated through the already established models that use the temperature in the wet period and the leaf wetness duration (LWD) as input variables. The meteorological data used covers a period of 10 years (from 2007 to 2016) obtained through the automatic meteorological station of the National Institute of Meteorology located in Santa Teresa, state of Espírito Santo, Brazil and the mean of the climatic variables used can be seen in Table 1. 
Table 1. Different substrates composition (treatments) used in Capsicum baccatum pepper seedling production

\begin{tabular}{ll}
\hline Treatment & Substrate Composition \\
\hline 0 & $100 \%$ Commercial Substrate \\
10 & $90 \%$ Commercial Substrate $+10 \%$ Tannery Sludge \\
20 & $80 \%$ Commercial Substrate $+20 \%$ Tannery Sludge \\
30 & $70 \%$ Commercial Substrate $+30 \%$ Tannery Sludge \\
40 & $60 \%$ Commercial Substrate $+40 \%$ Tannery Sludge \\
50 & $50 \%$ Commercial Substrate $+50 \%$ Tannery Sludge \\
60 & $40 \%$ Commercial Substrate $+60 \%$ Tannery Sludge \\
80 & $20 \%$ Commercial Substrate $+80 \%$ Tannery Sludge \\
\hline
\end{tabular}

The description of the tannery slurry and the commercial substrate used in the preparation of the substrates are described in Table 2 and 3, respectively.

Table 2. Chemical characteristics of tannery sludge used in the preparation of substrates for Capsicum baccatum pepper seedling production

\begin{tabular}{|c|c|c|c|c|c|c|}
\hline TOM $^{1}$ & $\mathrm{COM}^{2}$ & $\mathrm{OC}$ & $\mathrm{N}$ & $\mathrm{P}$ & $\mathrm{K}$ & $\mathrm{Ca}$ \\
\hline \multicolumn{7}{|c|}{$\begin{array}{l}-----1-1 \\
\end{array}$} \\
\hline 293.1 & 110.2 & 61.2 & 17.3 & 7.6 & 0.6 & 230.2 \\
\hline $\mathrm{Mg}$ & S & IC & $\mathrm{Cr}$ & $\mathrm{Na}$ & $\mathrm{B}$ & \\
\hline \multicolumn{7}{|c|}{ 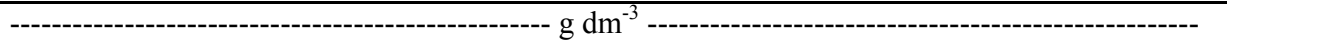 } \\
\hline 21.3 & 13.2 & 61.2 & 40.0 & 8.0 & 0.28 & \\
\hline
\end{tabular}

Note. $\mathrm{TOM}^{1}=$ total organic matter; $\mathrm{COM}^{2}=$ compostable organic matter; $\mathrm{OC}=$ organic carbon; $\mathrm{N}=$ nitrogen; $\mathrm{P}$ = phosphorus; $\mathrm{K}=$ potassium; $\mathrm{Ca}=$ calcium; $\mathrm{Mg}$ = magnesium; $\mathrm{S}=$ sulfur; $\mathrm{IC}=$ inorganic carbon; $\mathrm{Cr}=$ chromium; $\mathrm{Na}=$ sodium; and $\mathrm{B}=$ boron.

Table 3. Chemical characteristics of the commercial Bioplant ${ }^{\circledR}$ substrate used in the preparation of substrates for Capsicum baccatum pepper seedling production

\begin{tabular}{|c|c|c|c|c|c|c|c|}
\hline $\mathrm{pH}^{*}$ & $\mathrm{~N}$ & $P$ & $\mathrm{~K}$ & $\mathrm{Ca}$ & TOC & $\mathrm{OM}$ & $\mathrm{C} / \mathrm{N}$ \\
\hline & ---- & ----- & ----- & $--\mathrm{g} \mathrm{d}^{-}$ & --- & ---- & --------------- \\
\hline 5.62 & 6.2 & 15.5 & 4.4 & 18.4 & 210 & 522.1 & 33.9 \\
\hline
\end{tabular}

Note. * Hydrogenation potential $(\mathrm{pH})$ in $\mathrm{CaCl}_{2}\left(\mathrm{CaCl}_{2} \mathrm{pH}\right)$.

$\mathrm{N}=$ nitrogen; $\mathrm{P}=$ phosphorus; $\mathrm{K}=$ potassium; $\mathrm{Ca}=$ calcium; $\mathrm{TOC}=$ total organic carbon; $\mathrm{OM}=$ organic matter; $\mathrm{C} / \mathrm{N}=$ carbon/nitrogen ratio.

Two seeds were sown per cell and the seedlings were thinned 20 days after sowing in order to produce only one seed per cell. At 64 days after sowing, the seedlings were evaluated, and data were obtained from the following variables: plant height (PH), in cm; stem diameter (SD), in $\mathrm{mm}$; crown diameter (CD), in mm; leaf area (LA), in $\mathrm{cm}^{2}$; dry shoot mass (DSM), in grams (g); and dry root mass (DRM), in grams (g). For the evaluation of DSM and DRM, after measuring the other variables, the seedlings were deposited in paper bags which were placed in a forced ventilation oven at $105^{\circ} \mathrm{C}$ for 24 hours for subsequent measurement.

After the data was collected, the quality index of the seedlings was calculated by the Dickson quality index (DQI), adapted according to the methodology proposed by Dickson et al. (1960), respecting the equation:

$$
\mathrm{DQI}=\frac{\mathrm{TDM}}{\left(\frac{\mathrm{PH}}{\mathrm{SD}}\right)+\left(\frac{\mathrm{DSM}}{\mathrm{DRM}}\right)}
$$

where, TDM = total dry mass (DSM+DRM); PH = plant height $(\mathrm{cm}) ; \mathrm{SD}=$ stem diameter $(\mathrm{mm}) ; \mathrm{DSM}=$ shoot dry mass (g), and; DRM = dry root mass (g).

To identify a significant response from the seedlings to the tannery sludge added in the substrate, since they are quantitative effect, the Shapiro-Wilk normality test was performed at $5 \%$ probability $(p<0.05)$. Subsequently 
the data were submitted the analysis of regression variance for the linear and quadratic models. After the responses were significant, the coefficients of response equations already adjusted were obtained and the average values for each treatment were plotted in the dispersion graphs. Statistical analysis was performed using the open source software R (R Core Team, 2014).

\section{Results and Discussion}

Data from chemical analysis of tannery sludge indicated the presence of total organic matter $\left(293.1 \mathrm{~g} \mathrm{dm}^{-3}\right)$ and calcium $\left(230.2 \mathrm{~g} \mathrm{dm}^{-3}\right)$ in a higher percentage which is important for the formation of substrates for quality seedling production (Table 2). The analysis of variance of the models indicated that mainly the linear models, with the exception of the leaf area, were significant to explain the response to the tannery sludge in the substrate (Table 4).

Table 4. Analysis of variance and regression model variance for the pepper seedlings response to commercial substrates with different proportions of tannery sludge

\begin{tabular}{llll}
\hline Variable & $\mathrm{QM}_{\text {Treatment }}$ & Model & $\mathrm{QM}_{\text {Model }}$ \\
\hline PH & $167.502 *$ & Linear & $1056.4790 *$ \\
SD & $0.11543^{*}$ & Linear & $0.7291 *$ \\
CD & $250.753 *$ & Linear & $1595.8930^{*}$ \\
LA & $3.55160^{*}$ & Quadratic & $18.6000^{*}$ \\
DSM & $0.00157^{*}$ & Linear & $0.0099^{*}$ \\
RDM & $0.00050^{*}$ & Linear & $0.0028^{*}$ \\
DQI & $0.28474^{\mathrm{ns}}$ & - & - \\
\hline
\end{tabular}

Note. *significant at the significance level of $5 \%$ according to the $\mathrm{F}$ test $(p<0.05)$; ns $=$ not significant. PH-Plant height, SD-stem diameter, CD-crown diameter, LA-leaf area, DSM-dry shoot mass, DRM-dry root mass and DQI-Dickson quality index.

This findings are in agreement with Almeida et al. (2017) that addition of tannery sludge to a commercial substrate in Capsicum chinense seedlings, gave significant plant responses. In addition, the responses observed can be explained by the linear regression model, with the exception of the leaf area. The dispersion graphs of the averages show that there was a positive and direct response of the plants in to tannery sludge in the substrate, for the variables of stem diameter, plant height and crown diameter (Figures 1B, 1C and 1D).

By the estimation equation, it was possible to observe that the highest proportion of sludge used in this experiment $(80 \%)$ provided gains of $18.21 \mathrm{~cm}$ for plant height, $0.47 \mathrm{~mm}$ for stem diameter and $22.77 \mathrm{~cm}$ for crown diameter. Tannery sludge is rich in several important nutrients for plants, notably for the amount of nitrogen, which is an essential element needed in greater quantity, capable of directly interfering with the plant growth (Sales et al., 2018a; Berilli et al., 2019), participating directly in the formation of proteins and enzymes, chlorophyll etc. Similarly, Sales et al. (2018b) identified gains for the same characteristics evaluated in this work for passion fruit seedlings with the addition of up to $50 \%$ of tannery sludge in the substrate.

In relation to the leaf area (Figure 1A), the estimated value obtained with the addition of $80 \%$ of tannery sludge in the substrate was $2.5 \mathrm{~cm}^{2}$. The leaf area is a fundamental component for plants, since the larger is the leaf area, the greater the light uptake by the plant and the greater the production of metabolic energy, which will be responsible for the maintenance of plant metabolism and growth, as well as in determining the productivity of the plant (Koester et al., 2014; Sales et al., 2017).

Sales et al. (2018c) studying chlorophyll content in Schinus terebinthifolius Raddi seedlings cultivated in different substrates, showed that the addition of tannery sludge in the substrate positively favors chlorophyll content, as well as other organic materials added in other compounds. The higher organic matter content and nutrients of these substrates may result in higher chlorophyll production and cellular structures, resulting in a larger leaf area (Sales et al., 2017). 

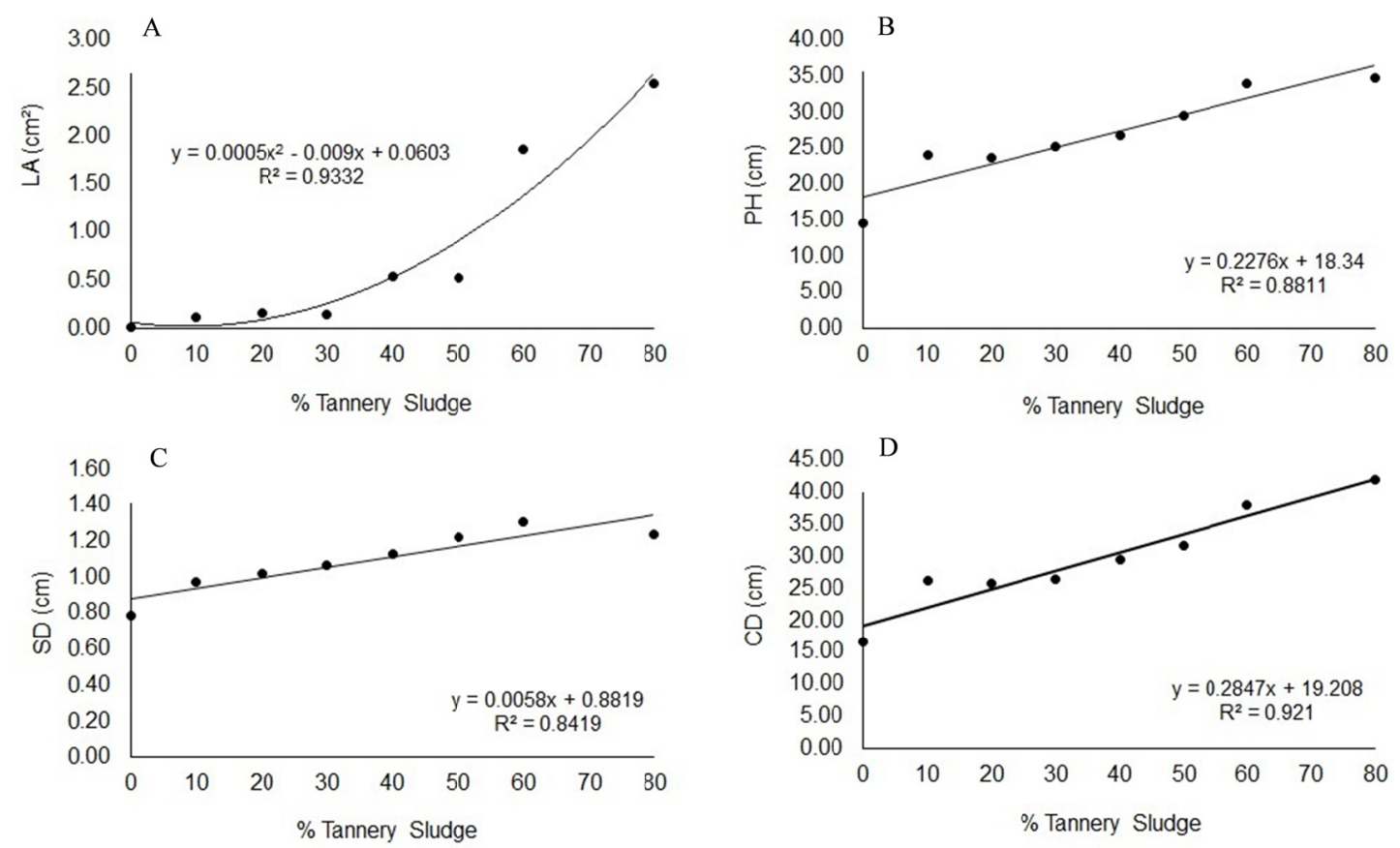

Figure 1. Dispersion graphs between agronomic characters: $\mathrm{A}=$ leaf area (LA), $\mathrm{B}=$ plant height $(\mathrm{PH}), \mathrm{C}=$ stem diameter (SD) and $\mathrm{D}=$ crown diameter (CD) of Capsicum baccatum pepper seedlings, due to different proportions of tannery sludge added to the commercial substrate

The values of root and shoot dry mass (Figures $2 \mathrm{~A}$ and $2 \mathrm{~B}$ ) show that the addition of tannery sludge in the substrate favors the incorporation of carbon. Once the leaf area gain was favored (Figure 1D), the plant presented a greater gain of photoassimilates, and consequently, a greater gain of root and shoot dry mass. With contrasting results, Berilli et al. (2014) studying tannery sludge in substrates for coffee seedlings production, identified that higher values of dry mass could be obtained in substrates with 20 to $30 \%$ of tannery sludge, however, according to the authors, resulted in seedling death. This may have occurred because they are different species, in addition, each batch of the residue contains a different composition, in which the levels of chromium and sodium, which are normally raised in the tannery, will vary.

The same fact that was not observed in this study, with good seedling growth for all the doses of sludge. It is worth emphasizing that this residue should be carefully used, since the characteristics of each lot or the different tanneries distributed throughout the country may vary and influence concentrations of existing beneficial or toxic elements in the process of tanning, thus affecting its use as fertilizer (Berilli et al., 2018b). Therefore, it is extremely important to know the concentrations of the elements through chemical analysis, since these elements present in the sludge can alter the characteristics of the development and the physiological characteristics, since there may be an accumulation of chromium in their tissues and also deleterious effects from the sodium (Berilli et al., 2015; Quartezani et al., 2018a, 2018b). 

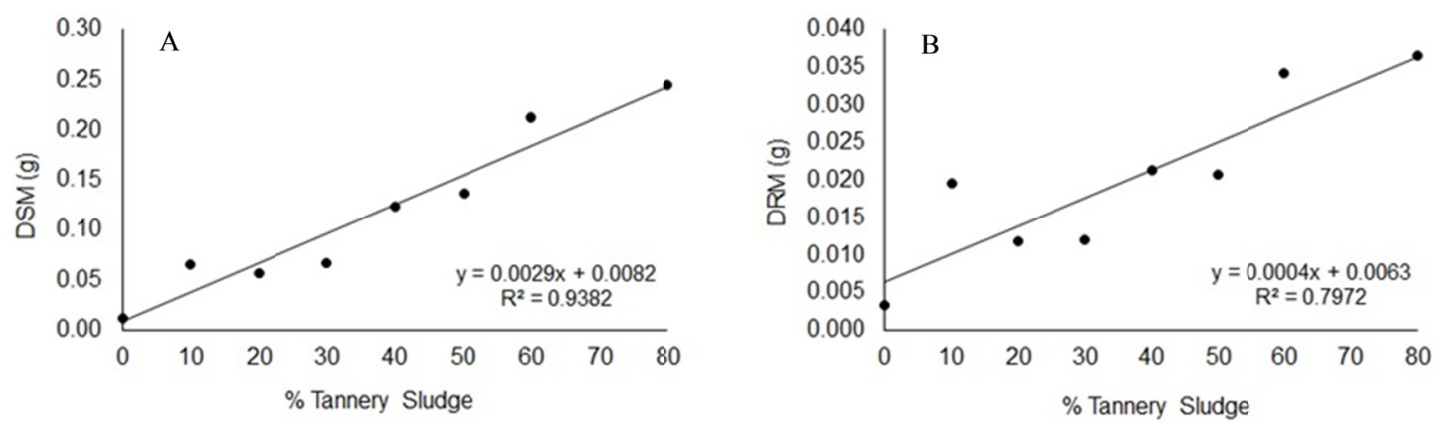

Figure 2. Dispersion graphs between agronomic characters: $\mathrm{A}=$ dry shoot mass (DSM) and $\mathrm{B}=$ dry root mass (DRM) of Capsicum baccatum pepper seedlings, due to different proportions of tannery sludge added to the commercial substrate

Considering the variables in general, the results indicate that doses from $10 \%$ guarantee increasing gains. The limit dose $(80 \%)$ of tannery sludge added to the substrate favored the development of pepper seedlings. These results differ from Almeida et al. (2017), in which doses above 70\% showed a decrease in the development of Capsicum chinense seedlings.

Such differences in the optimal doses for peppers, can be related to the genetic nature of the material used, since different genotypes may have different responses to environmental stimuli. Another factor, can be the difference in the nutrient content of different lots of residue used, considering that the interaction of the substrate can occur in different ways with the elements present in the tannery sludge, as a function of its composition (Quadro et al., 2018).

The $\mathrm{R}^{2}$ values obtained indicate that there is a satisfactory representation of the equations to predict plant growth in relation to the addition of sludge in the substrate. The lowest value of representation $\left(R^{2}=0.79\right)$, although still satisfactory was observed for dry root mass (Figure 2A).

By the estimation equation, it was possible to observe that the tannery sludge in the commercial substrate in the proportion of $80 \%$ of sludge and $20 \%$ of substrate resulted in an increase of $99 \%$ in plant height; $>1000 \%$ in leaf area; $52 \%$ for stem diameter; $118 \%$ for crown diameter; $507 \%$ for dry root mass; $>1000 \%$ dry shoot mass; in relation to the pure commercial substrate.

Finally, besides quality studies, due to food safety concerns, studies may also be carried out on chrome content in fruits, although it is already known that there is a tendency of accumulation in a smaller quantity in fruits. Nunes et al. (2018) studied the of chromium contents absorbed by sweet pepper fruits (Capsicum annuum L.) cultivated in substrate based on tannery sludge, identified that although there was presence of chromium in the fruits, these contents remained constant and did not reach values risk to health and food safety. It is also worth mentioning that the consumption of foods with certain levels of chromium is stimulated, mainly in the diet of athletes (Silva, 2014).

\section{Conclusion}

The addition of tannery sludge to commercial substrate promotes better development of Capsicum baccatum pepper seedlings, making it a good alternative to reduce production costs and possibly increase productivity.

The use of $80 \%$ of tannery sludge to $20 \%$ of commercial substrate presented significant gains and can be used in Capsicum baccatum pepper seedlings production.

\section{References}

Almeida, R. N., Ferraz, D. R., Silva, A. S., Cunha, E. G., Vieira, J. C., Souza, T. D. S., \& Berilli, S. D. S. (2017). Utilização de lodo de curtume em complementação ao substrato comercial na produção de mudas de pimenta biquinho. Scientia agraria, 18(1), 20-33. https://doi.org/10.5380/rsa.v18i1.49914

Alves, V. C., \& Barbosa, A. S. (2013). Práticas de gestão ambiental das indústrias coureiras de Franca-SP. Gestão \& Produção, 20(4), 883-898. https://doi.org/10.1590/S0104-530X2013005000006

Berilli, S. D. S., Quiuqui, J. P. C., Rembinski, J., Salla, P. H. H., Berilli, A. P. C. G., \& Louzada, J. M. (2014). Utilização de lodo de curtume como substrato alternativo para produção de mudas de café conilon. Coffe Science, 9(4), 472-479. 
Berilli, S. D. S., Berilli, A. P. C. G., Carvalho, A. J. C. D., Freitas, S. D. J., Cunha, M. D., \& Fontes, P. S. F. (2015). Níveis de cromo em mudas de café conilon desenvolvidas em substrato com lodo de curtume como adubação alternativa. Coffe Science, 10(3), 320-328.

Berilli, S. S., Martineli, L., Ferraz, T. M., Figueiredo, F. A. M. A., Rodrigues, W. P., Berilli, A. P. C. G., ... Freitas, S. J. (2018a). Substrate Stabilization Using Humus with Tannery Sludge in Conilon Coffee Seedlings. Journal of Experimental Agriculture International, 21(1), 1-10. https://doi.org/10.9734/ JEAI/2018/39851

Berilli, S. S., Pereira, L. C., Pinheiro, A. P. B., Cazaroti, E. P. F., de Sales, R. A., \& Lima, C. F. (2018b). Adubação foliar com lodo de curtume líquido no desenvolvimento e qualidade de mudas de maracujá-amarelo. Revista Brasileira de Agricultura Irrigada, 12(2), 2477-2486.

Berilli, S. S., Valadares, F. V., Sales, R. A., Ulisses, A. F., Pereira, R. M., Dutra, G. J. A., ... Almeida, R. N. (2019). Use of Tannery Sludge and Urban Compost as a Substrate for Sweet Pepper Seedlings. Journal of Experimental Agriculture International, 34(4), 1-9. https://doi.org/10.9734/jeai/2019/v34i430181

Chagas, J. F. R., Paz, S. A., Ventura, M. V. A., Costa, E. M., Mortate, R. K., Nunes, B. M., ... Santana, A. J. O. (2019). Propagation and Vegetative Development of Portulaca oleracea Linn. in Different Substrates. Journal of Agricultural Science, 11(7), 22-28. https://doi.org/10.5539/jas.v11n7p22

Dickson, A., Leaf, A. L., \& Hosner, J. F. (1960). Quality appraisal of white spruce and white pine seedling stock in nurseries. The Forestry Chronicle, 36(1), 10-13. https://doi.org/10.5558/tfc36010-1

Kehie, M., Kumaria, S., \& Tandon, P. (2016). Biotechnological enhancement of capsaicin biosynthesis in cell suspension cultures of Naga King Chili (Capsicum chinense Jacq.). Bioprocess Biosystem Engineering, 39, 205-210. https://doi.org/-10.1007/s00449-015-1504-6

Koester, R. P., Skoneczka, J. A., Cary, T. R., Diers, B. W., \& Ainsworth, E. A. (2014). Historical gains in soybean (Glycine max Merr.) seed yield are driven by linear increases in light interception, energy conversion, and partitioning efficiencies. Journal of Experimental Botany, 65(12), 3311-3321.

Mota, C. S., Silva, F. G., Dornelles, P., Freiberger, M. B., Reis, D. N., \& Mendes, G. C. (2018). Parameters of Physiology, Nutrition and Quality of Eugenia dysenterica DC Seedlings Grown in Organic Substrates from the Agricultural Industry. Journal of Agricultural Science, 10(1), 73-84. https://doi.org/10.5539/ jas.v10n1p73

Nunes, R. R., Pigatin, L. B. F., Oliveira, T. S., Bontempi, R. M., \& Rezende, M. O. O. (2018). Vermicomposted tannery wastes in the organic cultivation of sweet pepper: Growth, nutritive value and production. International Journal of Recycling of Organic Waste in Agriculture, 7, 313-324. https://doi.org/10.1007/ s40093-018-0217-7

Oliveira, F. D. A., Costa, J. P. B. M., Oliveira, M. K. T., Souza Neta, M. L., Bezerra, F. M. S., \& Cavalcante, A. L. G. (2015). Produção de mudas de pimentão utilizando fertirrigação. Revista de Ciências Agrárias/Amazonian Journal of Agricultural and Environmental Sciences, 58(3), 263-269. https://doi.org/ $10.4322 /$ rca. 1882

Quartezani, W. Z., Sales, R. A., Berilli, S. S., Pletsch, T. A., Rodrigues, W. P., Campostrini, E., ... Mantoanelli, E. (2018a). Effect of different sources of organic matter added to the substrate on physiological parameters of clonal plants of conilon coffee. Australian Journal of Crop Science, 12(08), 1328-1334.

Quartezani, W. Z., Sales, R. A., Pletsch, T. A., Berilli, S. S., Nascimento, A. L., Hell, L. R., ... Toso, R. (2018b). Conilon plant growth response to sources of organic matter. African Journal of Agricultural Research, 13(4), 181-188. https://doi.org/10.5897/AJAR2017.12801

Quadro, M. S., Andreazza, R., Tedesco, M. J., Gianelo, C., Barcelos, A. A., \& Bortolon, L. (2018). Teores de cromo ligados aos óxidos de ferro em áreas de descarte de lodo de curtume. Engenharia Sanitária e Ambiental, 23(1), 63-67. https://doi.org/10.1590/s1413-41522018159157

$\mathrm{R}$ Core Team. (2014). R: A Language and Environment for Statistical Computing. Retrieved from http://www.r-project.org

Sales, R. A., Sales, R. A., Nascimento, T. A., Silva, T. A., Berilli, S. S., \& Santos, R. A. (2017). Influência de diferentes fontes de matéria orgânica na propagação da Schinus terebinthifolius Raddi. Scientia Agraria, 18(4), 99-106. https://doi.org/10.5380/rsa.v18i4.54203 
Sales, R. A., Rossini, F. P., Berilli, S. S., Galvão, E. R., Mendes, T. P., Berilli, A. P. C. G., ... Freitas, S. J. (2018a). Foliar Fertilization Using Liquid Tannery Sludge in Conilon Coffee Seedlings Production. Journal of Experimental Agriculture International, 22(2), 1-8. https://doi.org/10.9734/JEAI/2018/40201

Sales, R. A., Sales, R. A., Prando, J. F., Berilli, S. S., Berilli, A. P. C. G., \& Coelho, M. B. (2018b). Lodo de curtume como fonte alternativa na composição se substrato de mudas de Passiflora edulis. Revista Ifes Ciência, 4(18), 107-115.

Sales, R. A., Sales, R. A., Santos, R. A., Quartezani, W. Z., Berilli, S. S., \& Oliveira, E. C. (2018c). Influência de diferentes fontes de matéria orgânica em componentes fisiológicos de folhas da espécie Schinus terebinthifolius Raddi. (Anacarciaceae). Scientia Agraria, 19(1), 132-141. https://doi.org/10.5380/rsa. v19i1.51511

Sediyama, M. A. N., Santos, I. C., \& Lima, P. C. (2015). Cultivo de hortaliças no sistema orgânico. Revista Ceres, 61, 829-837. https://doi.org/10.1590/0034-737x201461000008

Signorini, T., Renesto, E., Machado, M. F. P. S., Bespalhok, D. N., \& Monteiro, E. R. (2013). Diversidade genética de espécies de Capsicum com base em dados de isozimas. Horticultura Brasileira, 31, 534-539. https://doi.org/10.1590/S0102-05362013000400005

Silva Júnior, J. V., Beckmann-Cavalcante, M. Z., Brito, L. P. S., Avelino, R. C., \& Cavalcante, Í. H. L. (2014). Aproveitamento de materiais alternativos na produção de mudas de tomateiro sob adubação foliar. Revista Ciência Agronômica, 45(3), 528-536. https://doi.org/10.1590/S1806-66902014000300013

Silva, L. F. M. (2014). Teor de cromo em alimentos e ingestão dietética de cromo por atletas de basquetebol (Doutorado em Produção Vegetal, Universidade Estadual do Norte Fluminense Darcy Ribeiro, Campos dos Goytacazes).

\section{Copyrights}

Copyright for this article is retained by the author(s), with first publication rights granted to the journal.

This is an open-access article distributed under the terms and conditions of the Creative Commons Attribution license (http://creativecommons.org/licenses/by/4.0/). 